\title{
Spatial scale of genetic structuring in coastal cod Gadus morhua and geographic extent of local populations
}

\author{
Per Erik Jorde ${ }^{1,2, *}$, Halvor Knutsen ${ }^{1}$, Sigurd Heiberg Espeland ${ }^{2}$, Nils Chr. Stenseth ${ }^{1,2}$ \\ ${ }^{1}$ Institute of Marine Research, Flødevigen, 4817 His, Norway \\ ${ }^{2}$ CEES - Centre for Ecological and Evolutionary Synthesis, University of Oslo, PO Box 1066, Blindern, 0316 Oslo, Norway
}

\begin{abstract}
We estimated the spatial scale of genetically distinguishable populations of coastal Atlantic cod Gadus morhua using microsatellite DNA markers. Significant overall heterogeneity in allele frequencies was found among 5 cod samples $(\mathrm{n}=493)$ along a $79 \mathrm{~km}$ segment of the Norwegian Skagerrak coast $\left(F_{\mathrm{ST}}=0.0013 ; \mathrm{p}=0.021\right)$. Most ( 3 out of 4 ) samples separated by less than $30 \mathrm{~km}$ were genetically highly similar $\left(F_{\mathrm{ST}}<0\right)$, whereas more distantly separated samples were typically genetically different. This genetic differentiation pattern indicates a patchy population structure with local coastal cod populations being limited in geographic extent to approx. $30 \mathrm{~km}$ or less. The spatial structure is thus on the scale of local fjords, suggesting a role for local topography in shaping population structure. The population structuring of coastal cod is more fine-scaled than hitherto reported, but is consistent with mark-recapture studies and data on egg distributions, and emphasises the need to focus on local populations in the management of marine fishes.
\end{abstract}

KEY WORDS: Spatial scale $\cdot$ Coastal Atlantic cod $\cdot$ Gadus morhua $\cdot$ Local populations $\cdot$ Genetic differentiation $\cdot$ Microsatellites

Resale or republication not permitted without written consent of the publisher

\section{INTRODUCTION}

Structuring of species into local populations and the spatial scale of such structures have important implications for demography and population dynamics, ecological interactions, and evolution of the species. Spatial substructuring implies that the local breeding unit, or population, is numerically smaller than the total number of specimens in the general area may suggest. Stochastic processes in demography and genetics (random genetic drift: Wright 1978 and references therein) then assume more important roles than if the species consisted of a larger, panmictic unit. Reduction in the geographic extent of the habitat patch, or home range, also influences population dynamics because of the increased perimeter to interior area ratio, and there may exist a critical smallest patch area below which populations cannot be maintained (Holmes et al. 1994). Spatial substructuring further alters the stability of species interactions and opportunities for coexistence in both predator-prey and competitive systems (Kareiva et al. 1990). Spatial processes may significantly modify the dynamics of local populations by individual dispersal, by community processes and trophic interactions, and by spatially correlated factors (Bjørnstad et al. 1999). Such spatial processes are scale-dependent, and the issue of spatial scale is central to many contemporary topics in ecology and evolution.

The prevalence and importance of spatial structuring have also become increasingly apparent for marine organisms, as more powerful methods have been developed and applied to detect such structure. In the Atlantic cod Gadus morhua, early genetic investigations uncovered a weak, but large-scale, substructuring spanning thousands of kilometres and depicting an apparently linear increase in genetic differentiation with increasing distance (Mork et al. 1985). Later largescale studies confirmed and expanded on those find- 
ings, employing different genetic markers such as cDNA RFLP patterns (Pogson et al. 1995), microsatellite DNA polymorphisms (Pogson et al. 2001), and mitochondrial DNA sequence variation (Árnason 2004). The quantitatively weak structure and the apparent linear pattern by which genetic differentiation increases with increasing distance suggest (cf. Rousset 1997) that gene flow is prevalent in this species and that conspecifics are isolated primarily by geographic distance (but see Pogson et al. 2001 and Árnason 2004 for alternative explanations). The aforementioned genetic studies were all based on samples that were collected from a large geographic area, typically covering several thousand kilometers, and the observed genetic differentiation pattern at that spatial scale yields little information on the issue of local populations and their structuring.

In more or less continuous habitats characterizing parts of a species' range, the extent of local populations may be defined as the area over which local recruitment dominates over external sources. In Atlantic cod, as for many other marine species with a pelagic larval phase, the traditional view has been that external sources dominate throughout, also in coastal areas, due to larval drift with ocean currents (Hjort 1914, Caley et al. 1996). This view is challenged by recent findings of genetic substructuring (implying distinct local populations) in coastal cod, occurring on a spatial scale of a few hundreds of kilometers (Ruzzante et al. 2000, 2001) or less (Knutsen et al. 2003). Contrary to the pattern of isolation by distance that characterizes large-scale structures, no evidence has been found for the occurrence of increased genetic differentiation with increasing distance at this finer spatial scale (Fig. 1; data from Knutsen et al. 2003). The absence of an isolation-by-distance pattern in this area, consisting

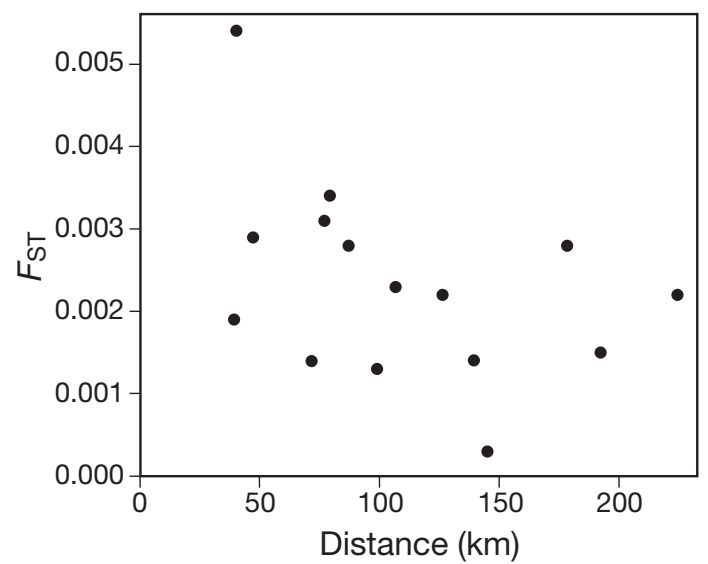

Fig. 1. Gadus morhua. Spatial pattern of genetic differentiation $\left(F_{\mathrm{ST}}\right)$ among Skagerrak coastal cod reported by Knutsen et al. (2003; data based on 10 microsatellite loci from their Table 4). Note that pairwise estimates are low, but consistently $>0$ throughout this spatial range of the Norwegian Skagerrak coast (see Fig. 2), is probably caused by larval drift from off-shore spawning grounds in the North Sea. Such larval drift has recently been detected directly, by observation of juvenile (0-group) cod genetically assigned to North Sea spawning samples (Knutsen et al. 2004), and indirectly, by its significant effect on juvenile coastal cod abundance in time series data from the Norwegian Skagerrak coast (Stenseth et al. 2006). Larval drift, if it produces successful recruits to the recipient coastal populations, represents gene flow that is expected to counteract the build-up of genetic differentiation among populations. The fact that we nevertheless do find detectable, albeit low, levels of genetic differentiation, shows that the coastal populations are not entirely swamped by gene flow. This observation suggests the existence of a spatial domain wherein local recruitment dominates, allowing some differentiation among local gene pools. The present study sought, by utilizing and expanding on the material of Knutsen et al. (2003), to test this hypothesis and to estimate the geographic extent of local coastal cod populations.

\section{MATERIALS AND METHODS}

Our study area was the Norwegian Skagerrak coastal range (Fig. 2) previously studied by Knutsen et al. (2003) and shown to harbour multiple cod popula-

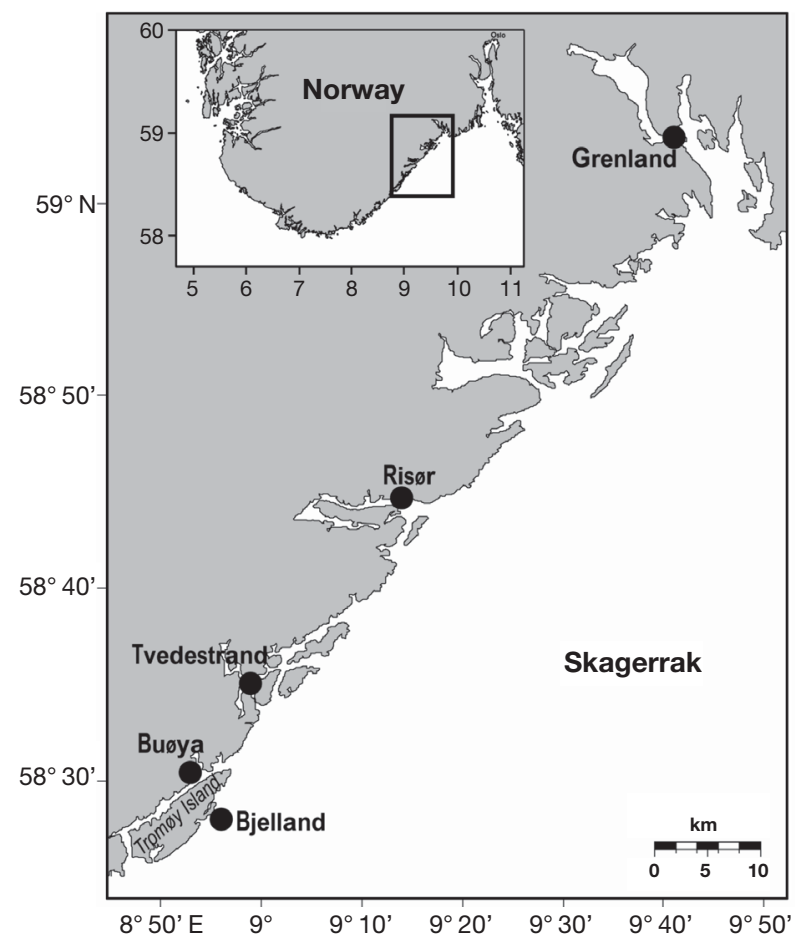

Fig. 2. Sampling area. (๑) Sampling sites; inset: southern Norway, sampling area boxed 
tions. The coastline consists of numerous small islands and skerries with small fjords or fjord-like basins extending up to a few $\mathrm{km}$ inland. Because Knutsen et al.'s (2003) study indicated that the level of local genetic differentiation was the same along the coast, we picked a sub-area for the present study that was conveniently situated and readily available for sampling. The sub-area comprised a $79 \mathrm{~km}$ segment of the coast that included 3 previous sample localities (Bjelland, Risør and Grenland) reported by Knutsen et al. in 2003. We expanded the sampling effort by including 2 additional localities (Buøya and Tvedestrand), situated among the 3 earlier ones (Fig. 2). The 5 sampling localities were separated by 8 to $79 \mathrm{~km}$ (measured as the shortest straight line between them) and represent a finer geographic scale than hitherto available for genetic analyses in coastal Atlantic cod. From each of the 5 localities about 100 adult Atlantic cod were sampled with gill nets, near presumed spawning sites in or near fjords. Sampling took place during the spawning season, in January to March, and was carried out using 3 to 4 gill nets (150 m each) over approximately $1 \mathrm{wk}$ until the required sample size was obtained (see Table 1).

All sampled cod were sexed by visual examination of the gonads, and assigned to a 5-point index of sexual maturity: cod were defined as mature if the gonads where either growing (Maturity Stage 2), ripe (Stage 3), or if the fish was spawning (Stage 4) or spent (Stage 5). The age was estimated for each individual from the number of hyaline zones deposited in the otoliths in late winter or spring, as observed under the microscope. White skeletal muscle was collected from each individual and stored in 96\% ethanol until DNA extraction and genetic analyses.

DNA was extracted from muscle tissue using the DNEASY kit (QIAGEN). The previous analyses of Knutsen et al. (2003) were based on 10 microsatellite loci. We expanded the number of loci to improve the statistical power to discriminate among populations, and included an additional 3 loci (Gmo8, Tch5, and Tch22) that have proved useful in other studies of Atlantic cod (e.g. Beacham et al. 2002, Hardie et al. 2006). Hence, a total of 13 microsatellite loci were amplified from extracted genomic DNA and screened for genetic variability, using PCR conditions that were slightly modified from those published (by excluding bovine serum albumin and by using a different brand of Taq polymerase and buffer [QIAGEN]): Gmo2 and Gmo132 (Brooker et al. 1994); Gmo3, Gmo8, Gmo19, Gmo34, Gmo35, Gmo36, and Gmo37 (Miller et al. 2000); Tch5, Tch12, Tch13, and Tch22 (O'Reilly et al. 2000). Microsatellite DNA fragments were separated and sized on an ALFexpress II automatic sequencer (Amersham Pharmacia Biotech).
Allele and genotype frequencies were estimated from genotype counts in the samples. Deviations from Hardy-Weinberg genotype proportions were quantified by $F_{\text {IS }}$ (estimator $f$ of Weir \& Cockerham 1984), and tested for using exact probability tests summed over loci using Fisher's summation procedure (GENEPOP software Version 3.3d, Raymond \& Rousset 1995). Amounts of genetic variation were characterised by average gene diversities within samples $\left(H_{\mathrm{S}}\right)$ and in the combined material $\left(H_{\mathrm{T}}\right)$ (Nei \& Chesser 1983). Genetic differentiation among samples was quantified by $F_{\mathrm{ST}}$, using estimator $\theta$ of Weir \& Cockerham (1984), and tested with an exact test for allele frequency heterogeneity among samples in GENEPOP. The joint nullhypothesis of no differentiation at any locus was tested by combining the single-locus p-values by Fisher's summation procedure, i.e. summing twice the negative logarithms of the single-locus p-values, as recommended by Ryman \& Jorde (2001). As an additional test for spatial differentiation we applied a permutation test for $F_{\mathrm{ST}}$, using the GENETIX software (Belkhir et al. 2002) with 10000 permutations. The permutation test was carried out both for each locus separately and over all 13 loci jointly. Finally, each fish was assigned to the most likely geographic origin (sample location) on the basis of its genotype and the spatial distribution of the other genotypes, using an assignment test in the WHICHRUN software (Banks \& Eichert 2000). In this assignment analysis the fish being assigned was not included in the base line data, i.e. we used the 'leaveone-out' procedure.

Possible relationships between genetic differentiation and geographic distance were tested by estimating $F_{\mathrm{ST}}$ (Weir \& Cockerham 1984) between pairs of samples and regressing these pair-wise $F_{\mathrm{ST}} /\left(1-F_{\mathrm{ST}}\right)$ values against shortest linear geographic distance between samples (Rousset 1997). Confidence limits for $F_{\text {ST }}$ were calculated by bootstrapping loci (10000 replicates), using the GDA software (Lewis \& Zaykin 2001). An AMOVA test (Excoffier et al. 1992) in the Arlequin software (Schneider et al. 1997) was used to decompose genetic variability into 2 components: within and among cohorts, respectively. This test, which was carried out in order to check temporal stability in the spatial genetic structure, utilised the fact that the cod samples included several different year classes or cohorts. However, some cohorts were represented by very few individuals in each sample (range 1 to 67 ind.) and we restricted the analyses to cohorts with at least 15 fish. Applying stricter statistical criteria and increasing this lower limit would yield too few cohorts for temporal comparisons in most samples. In addition to the AMOVA test we also estimated $F_{\mathrm{ST}}$ pair-wise among cohorts within the sample localities, and among localities for the same cohort, in order to 
separate and compare temporal and spatial genetic variability components. In this latter analysis we included cohorts with at least 10 ind. (rather than 15) to permit comparison of at least 1 cohort from each geographic sample (because the samples had somewhat different cohort compositions). All pair-wise comparisons were tested with an exact test for allele frequency differences, using the GENEPOP software.

\section{RESULTS}

The total sample comprised 493 fish from 5 different localities and scored at 13 microsatellite loci. The amount of genetic variability was very similar among sites $\left(H_{\mathrm{S}}\right.$ : Table 1$)$; however, individual loci differed greatly in variability (Table 2 ), with $H_{\mathrm{T}}$ ranging from 0.181 (Gmo3) to 0.927 (Tch5) and the total number of observed alleles ranged from 4 (Gmo36) to 49 (Gmo8).

The genotypic proportions within samples generally conformed to Hardy-Weinberg expectations (cf. Table 1). Without correcting for multiple tests there were apparently significant heterozygote deficiencies in the Risør sample at loci Gmo8, Gmo19, and Tch22 (each significant at the 5\% level), in Buøya at Gmo36 $(\mathrm{p}<0.01)$, and in Tvedestrand at Gmo37 ( $p<0.05)$. A significant heterozygote excess was observed at Locus Gmo2 in the Risør sample ( $p<0.05)$. Confounding factors such as segregation of null-alleles are often invoked as explanations for apparent heterozygote deficiencies in microsatellites (e.g. Pemberton et al. 1995), but were unlikely in the present case because all samples had quite similar allele frequencies, as reflected in the low (but significant: see below, this section) $F_{\mathrm{ST}}$-values. Hence, if present, null-alleles should segregate at the same locus and affect all samples to a similar extent, which was not the case. Likewise, we tentatively ruled out potential external forces such as
Table 2. Gadus morhua. Genetic variability at individual microsatellite loci, with observed number of alleles (a), mean gene diversity $\left(H_{\mathrm{T}}\right)$, and amount of variation among populations $\left(F_{\mathrm{ST}}\right)$ for each locus and averaged over all 13 loci. The null hypothesis $\left(F_{\mathrm{ST}}=0\right)$ was tested with a permutation test (p-perm) and with an exact test for allele frequency heterogeneity (p-exact). Bold: significant

\begin{tabular}{|lrrrrr|}
\hline \multirow{2}{*}{ Locus } & \multicolumn{2}{c}{ Within total } & \multicolumn{3}{c|}{ Between localities } \\
& $a$ & $H_{\mathrm{T}}$ & $F_{\mathrm{ST}}$ & $\mathrm{p}$-perm & p-exact \\
& & & & & \\
Gmo2 & 20 & 0.852 & 0.0000 & 0.456 & 0.184 \\
Gmo3 & 8 & 0.181 & 0.0014 & 0.231 & 0.185 \\
Gmo8 & 49 & 0.878 & 0.0011 & 0.082 & 0.161 \\
Gmo19 & 24 & 0.913 & 0.0013 & 0.131 & 0.263 \\
Gmo34 & 9 & 0.619 & 0.0028 & 0.100 & $\mathbf{0 . 0 3 9}$ \\
Gmo35 & 9 & 0.830 & 0.0020 & 0.111 & 0.088 \\
Gmo36 & 4 & 0.502 & 0.0078 & $\mathbf{0 . 0 3 2}$ & $\mathbf{0 . 0 4 8}$ \\
Gmo37 & 20 & 0.843 & 0.0022 & 0.078 & 0.159 \\
Gmo132 & 33 & 0.910 & 0.0028 & $\mathbf{0 . 0 1 8}$ & 0.205 \\
Tch5 & 32 & 0.927 & 0.0005 & 0.266 & 0.136 \\
Tch12 & 15 & 0.290 & -0.0003 & 0.452 & 0.541 \\
Tch13 & 37 & 0.920 & -0.0009 & 0.794 & 0.914 \\
Tch22 & 8 & 0.597 & -0.0023 & 0.791 & 0.694 \\
Mean & 20.6 & 0.712 & 0.0013 & $\mathbf{0 . 0 0 3}$ & $\mathbf{0 . 0 2 1}$ \\
SE & 3.8 & 0.070 & 0.0007 & & \\
\hline
\end{tabular}

natural selection-directly or acting through hitchhiking - because such effects should again be limited to particular loci (Gmo132 has been suspected; Nielsen et al. 2006). Summing over all 13 loci, no sample deviated significantly from Hardy-Weinberg expectations.

There were statistically significant differences in allele frequencies among the 5 samples (Table 2), with an average $F_{\mathrm{ST}}=0.0013$ over loci. The permutation test and the exact test both rejected the null hypothesis of no differentiation at 2 loci each, although there was some difference between the tests with regard to which loci were significantly different (Gmo36 and Gmo132 in the permutation test versus Gmo34 and Gmo36 in the exact test). Nearly significant genetic

Table 1. Gadus morhua. Sampled localities, no. of ind., percentage of mature ind., estimates of genetic variability $\left(H_{\mathrm{S}}\right)$, and deviations from Hardy-Weinberg genotype proportions within samples $\left(F_{\mathrm{IS}}\right)$. p: results of exact probability tests (GENEPOP: using 10000 dememorisation steps, 1000 batches, and 10000 iterations per batch, and averaged over 5 replicate runs), carried out for each locus and summed over loci using Fisher's summation procedure. Loci with significant (not corrected for multiple tests) deficiencies or excesses of heterozygotes are indicated $\left({ }^{*} p<0.05{ }_{i}^{* *} p<0.01\right)$

\begin{tabular}{|c|c|c|c|c|c|c|c|}
\hline \multirow[t]{2}{*}{ Locality } & \multirow[t]{2}{*}{$\mathrm{n}$} & \multirow[t]{2}{*}{ \% Mature } & \multirow{2}{*}{$\operatorname{Avg} H_{\mathrm{S}}$} & \multicolumn{4}{|c|}{ Deviations from Hardy-Weinberg proportions } \\
\hline & & & & $\operatorname{Avg} F_{\mathrm{IS}}$ & $\mathrm{p}$ & $\begin{array}{c}\text { Deficiencies } \\
\left(F_{\mathrm{IS}} \text { pos. }\right)\end{array}$ & $\begin{array}{l}\text { Excesses } \\
\left(F_{\mathrm{IS}} \text { neg. }\right)\end{array}$ \\
\hline Bjelland & 92 & 46.7 & 0.716 & 0.027 & 0.16 & & \\
\hline Вuøуа & 100 & 78.0 & 0.709 & -0.025 & 0.26 & Gmo36** & \\
\hline Tvedestrand & 100 & 84.0 & 0.716 & 0.008 & 0.24 & Gmo37* & \\
\hline Risør & 101 & 57.5 & 0.720 & 0.014 & 0.07 & Gmo19* Tch22* Gmo8* & Gmo2* \\
\hline Grenland & 100 & 64.0 & 0.698 & 0.013 & 0.26 & & \\
\hline Avg & 98 & 66.0 & 0.712 & 0.007 & & & \\
\hline $\mathrm{SE}$ & & & 0.004 & 0.009 & & & \\
\hline
\end{tabular}


differences $(p<0.10)$ were observed at 3 other loci (Gmo 8, Gmo35, and Gmo37; Table 2). When evaluating the joint null hypothesis of no differentiation at any locus, both the permutation and the exact tests yielded significant results $(\mathrm{p}=0.003$ and 0.021 , respectively; Table 2). The results of the assignment test (Fig. 3) were consistent with the results of the heterogeneity tests and assigned a much higher fraction of individuals to the locality at which they were sampled (range 51 to $70 \%$ ) than to any other site (range 4 to $14 \%$ ). Hence, genetic differentiation prevails even at a spatial scale $<79 \mathrm{~km}$ in coastal Atlantic cod.

In view of the small amount of differentiation among the samples $\left(F_{\mathrm{ST}}=0.0013\right)$, there is the possibility that observed differentiation was confounded by temporal genetic change within sample localities, i.e. by differences among age classes or cohorts (Waples 1998). Temporal fluctuations in allele frequency occur in all finite populations because of random genetic drift, generating some allele frequency differences among cohorts within the population (Jorde \& Ryman 1996). When the samples do not have exactly the same age composition the observed differences among samples will include a temporal component that may be mistaken for spatial differentiation. In the present case, however, it was possible to measure the temporal component directly, utilizing age information to classify each fish to a birth cohort. Applying AMOVA to the cohort data yielded a significant, positive estimate of $F_{\mathrm{ST}}=0.0017$ among geographic samples $(\mathrm{p}=0.023$, based on 10000 permutations), whereas the estimate between cohorts within samples was negative $(-0.0021)$ and not significantly larger than zero. The pair-wise $F_{\mathrm{ST}}$ (Table 3 ) added more details to this picture and uncovered predominantly positive estimates of differentiation among cohorts (Table 3: along diagonal), indicating some temporal change within samples. The estimated magnitude of this change (0.0023 averaged over pair-wise estimates) was, however, not significant within any locality (exact test, p-values ranging from 0.18 in Grenland to 0.97 in Buøya), nor for the average over samples $(p=0.14)$. Further, this temporal component was on average considerably smaller than that estimated within cohorts among different samples (Table 3: below diagonal; average $F_{\mathrm{ST}}=$ 0.0041). Several of these latter pairwise tests for spatial differentiation were significant (Table 3: below diagonal; 7 out of 10 tests were significant at the $5 \%$ level or better). Hence, both the results of the AMOVA and the pairwise $F_{\mathrm{ST}}$ analyses of cohorts demon-

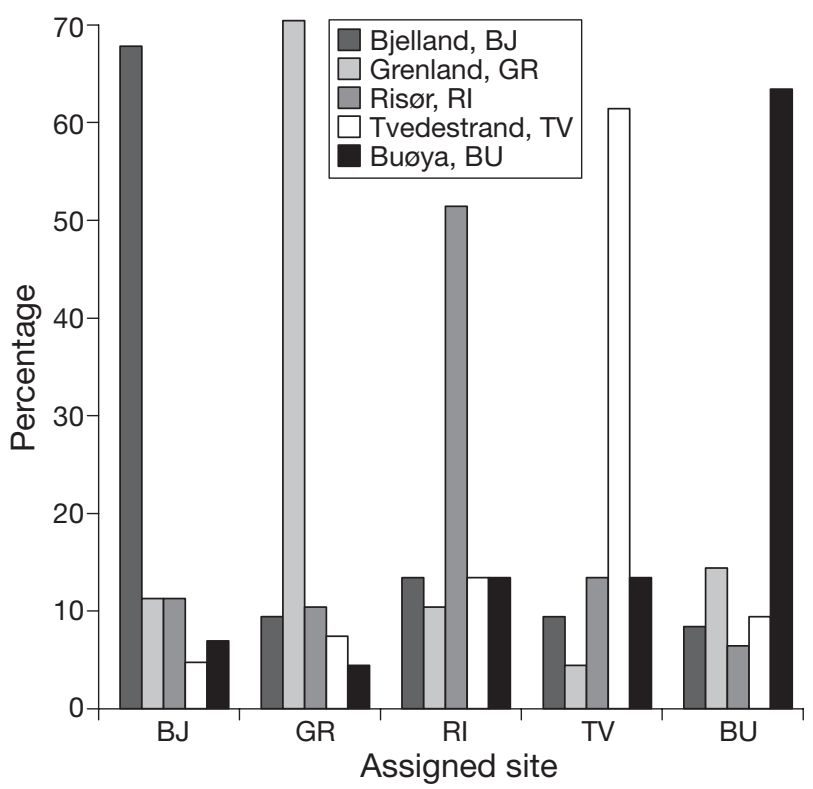

Fig. 3. Gadus morhua. Distribution of statistical assignment of sampled individuals based on genotypes at 13 microsatellite loci, showing percentage of individuals assigned to each sampling site. For all sampled localities a much higher fraction of individuals (51 to $70 \%$ ) was assigned to site of capture than to any other site (4 to $14 \%$ )

strate that the temporal component to the observed genetic differentiation in this study was smaller than the spatial component, and the observed spatial differentiation therefore cannot be explained by temporal change alone.

In view of the above findings, demonstrating that the observed genetic differentiation cannot be explained by temporal fluctuations among age classes, the following analyses utilised whole samples. Combining all age classes within samples we found that several sample-pair comparisons were statistically significant

Table 3. Gadus morhua. Mean pair-wise $F_{\mathrm{ST}}$ estimated from 13 microsatellite loci, among and within year classes (cohorts). Above diagonal: comparison of different cohorts in different geographic samples (avg. $F_{\mathrm{ST}}=0.0042$ ); along diagonal (bold): comparison of different cohorts within samples (i.e. temporal component, average $\left.F_{\mathrm{ST}}=0.0023\right)$; below diagonal: comparison of different geographic samples within same cohorts (i.e. spatial component, average $F_{\mathrm{ST}}=$ 0.0041). Only year classes with $\geq 10$ ind. are included in the table. ${ }^{*} \mathrm{p}<0.05$; ${ }^{* *} p<0.01$ based on exact tests of allele frequency heterogeneity

\begin{tabular}{|llccll|}
\hline & $\begin{array}{c}\text { Bjelland } \\
(3)\end{array}$ & $\begin{array}{c}\text { Buøya } \\
(3)\end{array}$ & $\begin{array}{c}\text { Tvedestrand } \\
(3)\end{array}$ & $\begin{array}{c}\text { Risør } \\
(4)\end{array}$ & $\begin{array}{c}\text { Grenland } \\
(3)\end{array}$ \\
\hline Bjelland & $\mathbf{0 . 0 0 3 6}$ & $0.0050^{*}$ & 0.0010 & $0.0013^{*}$ & 0.0062 \\
Buøya & $0.0010^{*}$ & $\mathbf{- 0 . 0 0 0 3}^{*}$ & $0.0030^{*}$ & $0.0069^{* *}$ & 0.0002 \\
Tvedestrand & 0.0024 & $0.0041^{*}$ & $\mathbf{0 . 0 0 3 4}$ & 0.0023 & $0.0046^{*}$ \\
Risør & $0.0068^{*}$ & $0.0111^{* *}$ & 0.0020 & $\mathbf{0 . 0 0 1 3}^{*}$ & $0.0094^{* *}$ \\
Grenland & $0.0034^{*}$ & 0.0006 & $0.0039^{*}$ & $0.0106^{* *}$ & $\mathbf{0 . 0 0 4 7}$ \\
\hline
\end{tabular}


Table 4. Gadus morhua. $F_{\mathrm{ST}}$ values among pairs of samples (below diagonal) and exact tests for differentiation ( $p$, above diagonal). Parentheses: sample size (all age classes combined). Bold: significant

\begin{tabular}{|lccccc|}
\hline & $\begin{array}{c}\text { Bjelland } \\
(92)\end{array}$ & $\begin{array}{c}\text { Buøya } \\
(100)\end{array}$ & $\begin{array}{c}\text { Tvedestrand } \\
(100)\end{array}$ & $\begin{array}{c}\text { Risør } \\
(101)\end{array}$ & $\begin{array}{c}\text { Grenland } \\
(100)\end{array}$ \\
\hline Bjelland & - & $\mathbf{0 . 0 5 0}$ & 0.687 & 0.250 & 0.070 \\
Buøya & 0.0031 & - & 0.247 & $\mathbf{0 . 0 0 7}$ & 0.139 \\
Tvedestrand & -0.0003 & -0.0001 & - & 0.452 & 0.210 \\
Risør & 0.0016 & 0.0030 & -0.0008 & - & $<\mathbf{0 . 0 0 1}$ \\
Grenland & 0.0020 & 0.0000 & 0.0008 & 0.0038 & - \\
\hline
\end{tabular}

from each other (Table 4). The linear regression of pair-wise $F_{\mathrm{ST}}$ values against geographic distance was close to zero $(\mathrm{b}=0.000014)$, and not significant. However, there was an apparent pattern, with most (3 out of 4) closely situated sample pairs (separated $<30 \mathrm{~km}$ apart) being genetically very similar (estimated $F_{\mathrm{ST}}<0$ among them), whereas more distant pairs had positive $F_{\mathrm{ST}}$ and were thus somewhat differentiated (Fig. 4). There were 2 exceptions to this general pattern (Fig. 4; Table 4): the closely situated sample pair Bjelland and Buøya (8 km apart) were significantly different from one another, whereas the more distantly separated (at $72 \mathrm{~km}$ ) pair Buøya and Grenland apparently were not.

\section{DISCUSSION}

Genetic methods are highly appropriate for delineating local populations because each generation's genes are transferred to the next generation, resulting in higher genetic similarity within the population boundary if members are predominantly recruited from local offspring. Herein, we have exploited this principle to

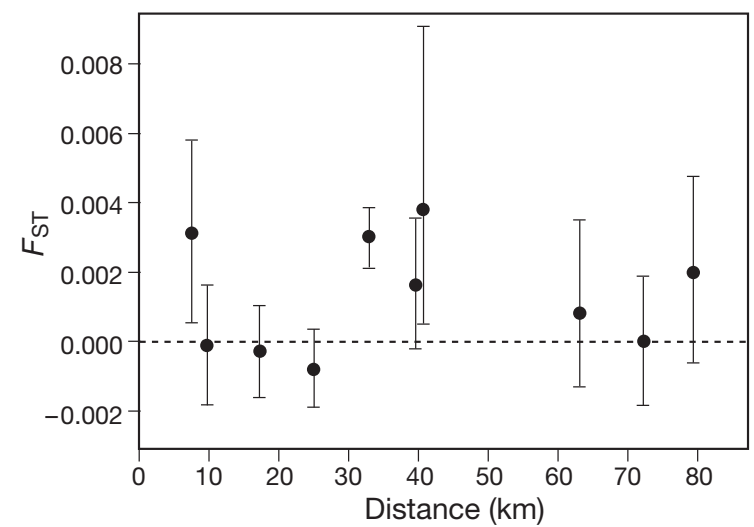

Fig. 4. Gadus morhua. Mean genetic differentiation $\left(F_{\mathrm{ST}}\right.$, averaged over 13 microsatellite loci: Table 4) among pairs of cod samples as a function of (straight-line) geographic separation. Vertical bars: $95 \%$ CI for estimated $F_{\mathrm{ST}}$, calculated by bootstrapping individual loci tentatively delineate local populations of Atlantic cod along a short segment of coastline. Delineating local populations of marine species has typically been a difficult task because of the weak genetic differentiation characterizing many marine organisms (Ward et al. 1994, Waples 1998). Genetic differentiation is indeed weak among the present Atlantic cod populations also, and our success in detecting differences at this spatial scale can be ascribed to the high statistical power resulting from employing relatively large numbers of microsatellites and sampled fish (see Ryman et al. 2006, Waples \& Gaggiotti 2006). As a consequence of the low level of differentiation, the point estimates $\left(F_{\mathrm{ST}}\right)$ are uncertain, as indicated by their wide CI (Fig. 4), and we would therefore expect that some pairwise comparisons would, by chance, be significant whereas others would not. The non-positive $F_{\mathrm{ST}}$ estimate between Buøya and Grenland, $72 \mathrm{~km}$ apart, most likely reflects such stochastic errors or 'noise', because other explanations seem to be biologically less plausible. Apart from this single pair, the tendency was for the more distant samples (>30 km apart) to be significantly differentiated genetically, reiterating our earlier findings (Knutsen et al. 2003 and present Fig. 1) and confirming the existence of multiple local cod populations along the Norwegian Skagerrak coast. This conclusion is strengthened by our demonstration herein that the observed differences among sample localities cannot be explained by genetic differences among age classes, and thus represent real spatial substructuring.

Among samples that were collected $<30 \mathrm{~km}$ apart we found no consistent genetic differentiation. On the contrary, 3 of the 4 pairwise comparisons below that distance yielded zero or negative estimates of $F_{\mathrm{ST}}$ and only 1 was positive and significant (between Bjelland and Buøya, $8 \mathrm{~km}$ apart). Again, statistical noise is a possible explanation for a deviating point estimate, especially since the $\mathrm{p}$-value in question was very close to the nominal alpha level of $5 \%$ (Table 4 ). On the other hand, it is also possible that the Bjelland sample (situated outside Tromøy Island; Fig. 2), is partly isolated from its neighbours and that Tromøy Island acts as a 'barrier' to free exchange between the 2 localities. Bathymetric and hydrodynamic structures have been shown to represent such barriers in Atlantic cod, e.g. between the Georges Bank and Browns Bank, about $80 \mathrm{~km}$ apart (Ruzzante et al. 1998) and over a saline gradient (Nielsen et al. 2003). It may also be of relevance that Bjelland was sampled further outside the fjords than were the other samples (perhaps outside the spawning area, as suggested by recent egg-density 
counts; Knutsen et al. 2007). This sample also contained a lower percentage of mature fish $(<50 \%$ : Table 1), and it is unclear to what extent it represented a spawning population. The assignment analysis (Fig. 3), (which showed consistently higher assignment to capture site than to any other locality, including neighbouring sites), indicated that all 5 samples might have represented (slightly) differentiated populations. A similar interpretation seems reasonable from the results of the spatio-temporal analyses (Table 3 and AMOVA), which did not uncover any tendency for neighbouring samples to vary temporally in a concerted fashion, as might be expected were they drawn from the same biological population (e.g. Jorde \& Ryman [1996] found highly correlated temporal allele frequency changes in brown trout from 2 interconnected lakes). Hence, there is a possibility for differentiation at an even finer geographic scale than the $30 \mathrm{~km}$ inferred from Fig. 4.

The observed genetic differentiation pattern indicates a patchy population structure in coastal Atlantic cod, with the geographic extent of the population unit being limited to $\leq 30 \mathrm{~km}$. Assuming that individual fish for the most part restrict their movements within the population boundary (or 'home range'), we compared our estimate with the large body of traditional capture-mark-recapture (CMR) data that have accumulated on Norwegian Skagerrak coastal cod (Løversen 1946, Moksness \& Øiestad 1984, Danielssen \& Gjøsæter 1994). We applied the 'minimum convex polygon' method (MCP; Mohr 1947) to estimate area utilization of coastal cod for CMR data from Danielssen \& Gjøsæter (1994). The data represent 1624 cod that were captured, marked, and released in the Risør fjord (in the middle of the present study area: Fig. 2) during 1988 and 1989, and yielded a total of 455 recaptures, $95 \%$ of which were found within a polygon area estimated to be $123 \mathrm{~km}^{2}$. This estimate represents the approximate asymptotic value, achieved after the fish had been at sea for about 1 yr (375 d) before recapture, and corresponds to $\sim 13 \mathrm{~km}$ of coastline. The estimate is clearly consistent with our present genetically determined size of local populations, and also with the earlier studies (Løversen 1946, Moksness \& Øiestad 1984, Danielssen \& Gjøsæter 1994) that concluded that coastal cod is 'highly stationary'. Other evidence for a restricted geographic extent of coastal populations of cod is provided by egg density studies. Knutsen et al. (2007) found strong evidence for retention of eggs within separate fjords along the Norwegian coast, in the Skagerrak, and elsewhere. Their findings imply restricted mixing of pelagic eggs and larvae, which should facilitate the build-up of genetic differentiation among coastal populations located in separate fjords. Both our genetic findings and those based on tradi- tional methods are thus congruent in suggesting that coastal cod are structured on a spatial scale of the order of local fjords. This observation suggests that fjords and other coastal structures (bays, islands, etc.) may play an important role in shaping the structure and geographic extent of fish populations in coastal areas.

The broader picture of coastal cod populations and related off-shore breeding stock(s) that emerges from the present and recent studies is that of a complex of geographically restricted coastal populations. Coastal populations in the Skagerrak appear largely selfrecruiting, as indicated by their partial (i.e. weak) genetic distinctness, but seem partly open to (and most likely receive) recruits from off-shore sources in the North Sea. An average number of 108 recruits successfully entering each coastal population per generation would be sufficient to explain the observed level of genetic differentiation among cod in the Skagerrak (Stenseth et al. 2006). However, the number of larvae (and recruits) probably fluctuates widely among years, and the inflow of North Sea larvae may be restricted to years when ocean currents during the spawning period are favourable for transportation of larvae into Skagerrak coastal waters (Knutsen et al. 2004). Current research focuses on the temporal aspect of larval drift and on recruitment of cod of North Sea origin to the coastal populations. Beyond its direct impact on the dynamics and ecology of the recipient coastal populations (Stenseth et al. 2006) there are also interesting evolutionary implications for such larval drift (e.g. Strathmann et al. 2002). We are currently approaching these and related questions with a combination of genetic analyses, CMR studies, oceanographic modelling, and time series analyses of juvenile cod abundance along the Skagerrak coast.

Knowledge of the spatial extent of local populations has numerous practical applications, both for research and for management. Such knowledge is instrumental in devising proper sampling strategies for estimating ecological parameters (including rates of reproduction, mortality and dispersal) as well as genetic parameters (including sampling baseline populations for statistical assignment and for mixed fishery analyses). The findings of the present study were directly applied in a recent project involving mathematical modelling of time-series data (Stenseth et al. 2006). Such modelling requires a priori partitioning of the sampling 'stations' into population units (Chan et al. 2003), and our present results show that data from quite small segments of a coastline (e.g. single fjords) may be joined in such statistical modelling.

The small geographic extent of local populations in coastal Atlantic cod provides a possible explanation for the strikingly dissimilar pattern of decline in cod abun- 
dance characterizing different areas of the Skagerrak coast (cf. Svedäng 2003). With distinct coastal populations and restricted movement among them, as indicated by our findings, there may not be sufficient export of spawners to rebuild overexploited or otherwise depleted cod populations (e.g. Waples 1998). The implication of these observations for the management of Atlantic cod and other marine species is clear and there is an obvious need to focus on local populations (Wroblewski et al. 2005).

Acknowledgements. This work was supported by the Research Council of Norway through a Strategic Institute Programme. We thank Kate and Svein E. Enersen, Henry Knutsen and Jan A. Knutsen for practical assistance. Three anonymous referees provided valuable comments on an earlier version of this paper. We thank Jakob Gjøsæter for access to CMR data on coastal cod.

\section{LITERATURE CITED}

Árnason E (2004) Mitochondrial cytochrome b DNA variation in the high-fecundity Atlantic cod: trans-Atlantic clines and shallow gene genealogy. Genetics 166:1871-1885

Banks MA, Eichert W (2000) WHICHRUN (Version 3.2) a computer program for population assignment of individuals based on multilocus genotype data. J Hered 91:87-89

Beacham TD, Brattey J, Miller KM, Le KD, Withler RE (2002) Multiple stock structure of Atlantic cod (Gadus morhua) off Newfoundland and Labrador determined from genetic variation. ICES J Mar Sci 59:650-665

Belkhir H, Borsa P, Chikhi L, Raufaste N, Bonhomme F (2002) GENETIX 4.04, logiciel sous Windows ${ }^{\mathrm{TM}}$ pour la génétique des populations. Laboratoire Génome, Populations, Interactions, CNRS UMR 5000, Université de Montpellier II

Bjørnstad ON, Ims RA, Lambin X (1999) Spatial population dynamcs: analyzing patterns and processes of population synchrony. Trends Ecol Evol 14:427-432

Brooker AL, Cook D, Bentzen P, Wright JM, Doyle RW (1994) Organization of microsatellites differs between mammals and cold-water teleost fishes. Can J Fish Aquat Sci 51: 1959-1966

Caley MJ, Carr MH, Hixon MA, Hughes TP, Jones GP, Menge BA (1996) Recruitment and the local dynamics of open marine populations. Annu Rev Ecol Syst 27:477-500

Chan KS, Stenseth NC, Kittilsen MO, Gjøsæter J, Lekve K, Smith T, Tveite S, Danielssen D (2003) Assessing the effectiveness of releasing cod larvae for stock improvement with monitoring data. Ecol Appl 13:3-22

Danielssen DS, Gjøsæeter J (1994) Release of 0-group cod, Gadus morhua L., on the southern coast of Norway in the years 1986-1989. Aquat Fish Manag 25:129-142

Excoffier L, Smouse P, Quattro J (1992) Analysis of molecular variance inferred from metric distances among DNA haplotypes: application to human mitochondrial DNA restriction data. Genetics 131:479-491

Hardie DC, Gillett RM, Hutchings JA (2006) The effects of isolation and colonization history on the genetic structure of marine-relict populations of Atlantic cod (Gadus morhua) in the Canadian Arctic. Can J Fish Aquat Sci 63:1830-1839

Hjort J (1914) Fluctuations in the great fisheries of northern Europe, viewed in the light of biological research. Rapp
P.-V Réun Cons Perm Int Explor Mer 20:1-228

Holmes EE, Lewis MA, Banks JE, Veit RR (1994) Partial differential equations in ecology: spatial interactions and population dynamics. Ecology 75:17-29

Jorde PE, Ryman N (1996) Demographic genetics of brown trout (Salmo trutta) and estimation of effective population size from temporal change of allele frequencies. Genetics 143:1369-1381

Kareiva P, Mullen A, Southwood R (1990) Population dynamics in spatially complex environments: theory and data [and discussion]. Philos Trans R Soc B 330:175-190

Knutsen H, Jorde PE, André C, Stenseth NC (2003) Finescaled geographic population structuring in a highly mobile marine species: the Atlantic cod. Mol Ecol 12:385-394

Knutsen $\mathrm{H}$, André C, Jorde PE, Skogen MD, Thuróczy E, Stenseth NC (2004) Transport of North Sea cod larva into the Skagerrak coastal populations. Proc R Soc B 271: $1337-1344$

Knutsen H, Olsen EM, Ciannelli L, Espeland S, Knutsen JA, Simonsen JH, Skreslet S, Stenseth NC (2007) Egg distribution, bottom topography and small-scale cod population structure in a coastal marine system. Mar Ecol Prog Ser 333:249-255

Lewis PO, Zaykin D (2001) Genetic data analysis: computer program for the analysis of allelic data. Version 1.0 (d16c). Free program distributed by the software authors over the internet available at http://hydrodictyon.eeb.uconn.edu/ people/plewis/software.php

Løversen R (1946) Torskens vekst og vandring på Sørlandet. Fiskeridir Skr Ser Havunders 8:1-27

Miller KM, Le KD, Beacham TD (2000) Development of triand tetranucleotide repeat microsatellite loci in Atlantic cod (Gadus morhua). Mol Ecol 9:238-239

Mohr CO (1947) Table of equivalent populations of North American small mammals. Am Midl Nat 37:223-249

Moksness E, Øiestad V (1984) Tagging and release experiments of 0-group coastal cod (Gadus morhua). Flødevigen Rapp 1:787-794

Mork J, Ryman N, Ståhl G, Utter F, Sundnes G (1985) Genetic variation in Atlantic cod (Gadus morhua) throughout its range. Can J Fish Aquat Sci 42:1580-1587

Nei M, Chesser RK (1983) Estimation of fixation indices and gene diversities. Ann Hum Genet 47:253-259

Nielsen EE, Hansen MM, Ruzzante DE, Meldrup D, Grønskjær P (2003) Evidence of a hybrid-zone in the Atlantic cod (Gadus morhua) in the Baltic and the Danish Belt Sea revealed by individual admixture analysis. Mol Ecol 12: $1497-1508$

Nielsen EE, Hansen MM, Meldrup D (2006) Evidence of microsatellite hitch-hiking selection in Atlantic cod (Gadus morhua L.): implications for inferring population structure in nonmodel organisms. Mol Ecol 15:3219-3229

O'Reilly PT, Canino MF, Bailey KM, Bentzen P (2000) Isolation of twenty low stutter di- and tetranucleotide microsatellites for population analyses of walleye pollock and other gadoids. J Fish Biol 56:1074-1086

Pemberton JM, Slate J, Bancroft DR, Barrett JA (1995) Nonamplifying alleles at microsatellite loci: a caution for parentage and population studies. Mol Ecol 4:249-252

Pogson GH, Mesa KA, Boutilier RG (1995) Genetic population structure and gene flow in the Atlantic cod Gadus morhua: a comparison of allozyme and nuclear RFLP loci. Genetics 139:375-385

Pogson GH, Taggart CT, Mesa KA, Boutilier RG (2001) Isolation by distance in the Atlantic cod, Gadus morhua, at large and small geographic scales. Evolution 55:131-146 Raymond M, Rousset F (1995) GENEPOP (Version-1.2) Popu- 
lation genetics software for exact tests and ecumenicism. J Hered 86:248-249

Rousset F (1997) Genetic differentiation and estimation of gene flow from $F$-statistics under isolation by distance. Genetics 145:1219-1228

Ruzzante DE, Taggart CT, Cook D (1998) A nuclear DNA basis for shelf- and bank-scale population structure in northwest Atlantic cod (Gadus morhua): Labrador to Georges Bank. Mol Ecol 7:1663-1680

Ruzzante DE, Wroblewski JS, Taggart CT, Smedbol RK, Cook D, Goddard SV (2000) Bay-scale population structure in coastal Atlantic cod in Labrador and Newfoundland, Canada. J Fish Biol 56:431-447

Ruzzante DE, Taggart CT, Doyle RW, Cook D (2001) Stability in the historical pattern of genetic structure of Newfoundland cod (Gadus morhua) despite the catastrophic decline in population size from 1964 to 1994 . Conserv Genetics 2: 257-269

Ryman N, Jorde PE (2001) Statistical power when testing for genetic differentiation. Mol Ecol 10:2361-2373

Ryman N, Palm S, André C, Carvalho GR and 6 others (2006) Power for detecting genetic divergence: differences between statistical methods and marker loci. Mol Ecol 15: 2031-2045

Schneider S, Roessli D, Excoffier L (1997) Arlequin. A software for population genetics data analysis. Available at: http:// lgb.unige.ch/arlequin/

Stenseth NC, Jorde PE, Chan KS, Hansen E, Knutsen H,

Editorial responsibility: Howard Browman (Associate Editorin-Chief), Storebø, Norway
André C, Skogen MD, Lekve K (2006) Ecological and genetic impact of Atlantic cod larval drift in the Skagerrak. Proc R Soc B 273:1085-1092

Strathmann RR, Hughes TP, Kuris AM, Lindeman KC, Morgan SG, Pandolfi JM, Warner RR (2002) Evolution of local recruitment and its consequences for marine populations. Bull Mar Sci 70 (Suppl):377-396

Svedäng H (2003) The inshore demersal fish community on the Swedish Skagerrak coast: regulation by recruitment from offshore sources. ICES J Mar Sci 60:23-31

Waples RS (1998) Separating the wheat from the chaff: patterns of genetic differentiation in high gene flow species. J Hered 89:438-450

Waples RS, Gaggiotti O (2006) What is a population? An empirical evaluation of some genetic methods for identifying the number of gene pools and their degree of connectivity. Mol Ecol 15:1419-1439

Ward RD, Woodmark M, Skibinski DOF (1994) A comparison of genetic diversity levels in marine, freshwater and anadromous fishes. J Fish Biol 44:213-232

Weir BS, Cockerham CC (1984) Estimating F-statistics for the analysis of population structure. Evolution 38:1358-1370

Wright S (1978) Evolution and the genetics of populations, Vol. 4. Variability within and among natural populations. University of Chicago Press, Chicago, IL

Wroblewski J, Neis B, Gosse K (2005) Inshore stocks of Atlantic cod are important for rebuilding the east coast fishery. Coastal Manag 33:411-432

Submitted: February 21, 2006; Accepted: February 15, 2007 Proofs received from author(s): July 24, 2007 